\title{
THE IMPORTANCE OF TRADE IN SERVICES AND ENVIRONMENTAL AMENITIES TO THE LOCATION OF PRODUCER SERVICE ACTIVITIES IN THE WESTERN UNITED STATES
}

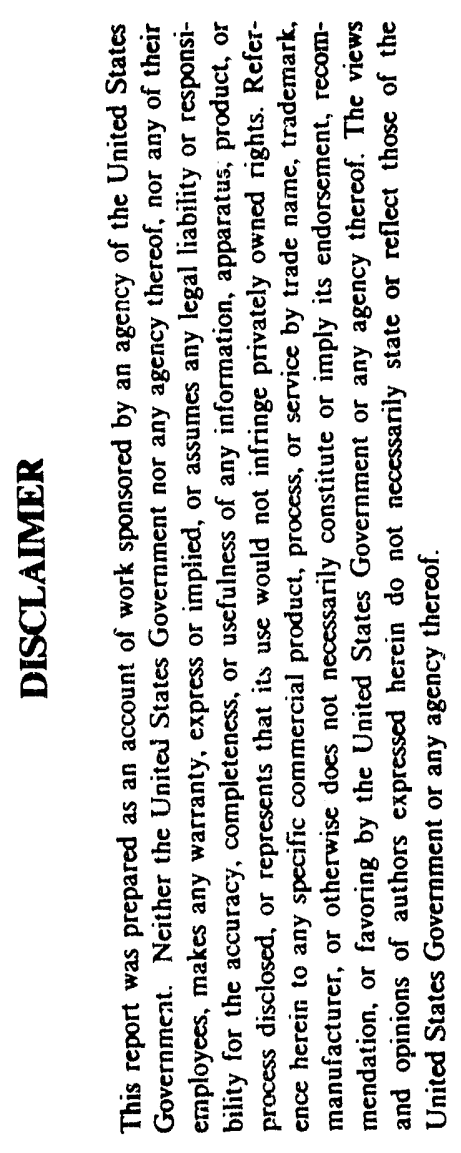

\author{
by \\ Tim Allison* \\ Argonne National Laboratory, EID 900 \\ 9700 South Cass Avenue \\ Argonne, IL 60439-4815 \\ Paper prepared for presentation at \\ The North American Meetings of \\ The Regional Science Association \\ New Orleans, LA \\ November, 1991
}

JUN 341992

* Work supported by the U.S. Department of Energy, Office of Civilian Radioactive Waste Management, under contract W-31-109-Eng-38. 


\section{Introduction}

The use of business services has had an increasingly important effect on economic performance in many industries, with the ability of firms in a given location to respond to changes in external markets, production techniques and material supplies often determined by the local provision of business information. Consequently, an increasing research effort has focused on the characteristics and role of producer services activities at the regional and urban economics (Beyers and Alvine 1985; Daniels 1985; Coffey 1987; Noyelle and Stanback 1984).

From a policy perspective, this research has become essential to new regional development initiatives with the cost of attracting service activities may be less substantial than for manufacturing industries, where service activities do not face severe foreign competition and do not require considerable investment in capital equipment. Particular attention has been given to higher order producer service activities, such as marketing and engineering consulting and production design, because of their potenti:d contribution to export growth (Marshall 1983, 1986; Beyers 1989; Drennan 1989).

It is not clear however, exachiy which factors are important to the provision of producer service activities, and the nature of their contribution to local and regional economic development. Although considerable empirical work remains to be undertaken on the contribution of these services, two schools of thought persist in the literature.

Firstly, growth in employment in service activities has often been closely related to changes in demand for services from within the manufacturing ses,or (Marshall 1983; Beyers 1989). Changes in demand for services from within multi-site firms have led to the internalization of certain services and the externalization of others. The chcice between either strategy may be dependent on either a need to increase specialization in certain service activities, or the need to achieve economies of scale in the firms main product. Both strategies may have negative impacts on the local provision of services if services are imported from outside the local economy, either from other parts of the same firm, or from independent service firms, to replace services previously provided locally.

A second view suggests that the spatial pattern of demand for services by manufacturing and other multi-site firms reflects, rather than determines, differences in the spatial distribution of service activities. There has been a trend toward the concentration of many business service activities and other high-order producer service functions in the larger metropolitan cities in the U.S. This may mean that businesses in smaller metropolitan places and peripheral locations requiring inputs from producer service activities may find it increasingly difficult to compete with firms in more central locations.

Essential to the nature and contribution of producer service activities to regional growth and development is, therefore, the extent to which spatial proximity to sources of demand and supply for producer service activities determine the ability to compete, and growth performance of independent producer service firms. Developments in transportation and especially telecommunications technologies have made proximity to demand centers less of an issue for 
service providers. Service product may be delivered to customers using a range of data transmission and telecommunications products from service activities located in peripheral locations. Increasing evidence in the literature suggests that there has been significant growth in the interregional import and export of a range of services, some of which are essential to the efficient operation of manufacturing production (Beyers and Alvine 1985; Beyers 1989; Coffey and Polese 1988).

Given the increasingly specialized nature of service outputs produced by producer service activities, many producer service activities are required to maintain scientific and technical occupations in order to provide competitive service products. Although the highly qualified personnel to fill these positions may be found in a variety of locations it is becoming apparent that thic attraction of certain locations for these occupational groups may only be partly related to existing employment opportunities. Firms reliant on these occupational groups may face shortages of personnel in some regional labor markets, and may consequently be drawn toward locations with a strong provision of scientific and technical occupations. These may be the peripheries of major metropolitan areas, smaller regional centers, or even places with specialized functions, such as university towns or concentrations of research facilities. These may be peripheral to demand centers for producer service activities, but may draw producer service activities through their provision of amenities in the natural and cultural environment.

This paper examines the nature and extent of external linkages of a sample of independent producer service firms in the two regional centers of Denver and Salt Lake City. Preliminary results are presented from a larger survey of local and regional factors important to the location of producer service activity using survey data collected from producer service activities in metropolitan and non-metropolitan places in Colorado and Utah. Findings are presented in three main areas of interest: the importance and geographic sources of subcontracting of business services by producer service establishments, particularly those establishments where scientific and technical occupations are an important location factor; the geographic and sectoral distribution of service sales; and the relative importance of various environmental amenities to the location of producer service activities.

\section{Survey Data}

Data for the paper was collected through telephone surveys of producer service establishments, as part of a larger survey conducted by the West Virginia University Survey Research Center that attempted to identify factors important to the location and growth of producer service activities. Establishments were identified from directories produced by Chambers of Commerce in the majority of cities in the states of Colorado and Utah, and selected for inclusion in the survey if it was clear that the main product of each establishment was marketed primarily to other business establishments. Product information was given in some cases in the listings, but for the majority of businesses chosen, the nature of service output was estimated from activity classifications used in the directories. An additional check was made in the survey itself, asking respondents to state whether more than $50 \%$ of output was marketed to consumers or other businesses over the previous three years. 
A total of 577 producer service establishments were contacted in the survey, producing 214 usable responses, giving a response rate was $42.1 \%$. Table 1 shows the geographic location of establishments responding to the survey. Establishments in Greater Denver, Colorado Springs in Colorado, and the Greater Salt Lake City area in Utah clearly dominate the responses.

\section{Characteristics of Respondent Service Establishments}

Table 2 shows the business services provided by the establishments in the sample. 97 establishments in the sample $(45 \%)$ provided the consulting services listed, computer and communications services were provided by $38(18 \%)$ establishments. and marketing and graphics services by 33 establishments (15\%).

Table 3 shows the organizational and employment characteristics of establishments surveyed. $128(60 \%)$ of the establishments were single location establishments, 48 (22\%) described themselves as establishments of multi-site service firms, and $31(14.5 \%)$ as headquarters establishments. A furthur 6 establishments identified themselves as regional or local sales offices, service establishments of multi-site manufacturing firms and data entry/processing functions. Full-time employment characteristics of each establishment show small and medium size establishments to be the typical establishment size for single plant firms, with a more even distribution across the three employment sizes for multi-site firms. Headquarters establishments seem to be typically more than 20 full-time employees.

An important caveat should be added at this point. Use of the Chambers of Commerce listings as the source of producer service establishments may have produced a sample of firms with marketing services in the local and regional rather than national economies. Establishments describing themselves as establishments of multi-site service firms in these listings were typically service firms with a number of local branches, than the regional operations of national corporations.

\section{Sources of Business Services for Producer Service Establishments}

The tendency toward subcontracting of peripheral activities by multi-site firms to specialist producer service firms has become increasingly common. Many large and medium size firms have made permanent changes in their organizational policy in favor of more flexible and decentralized structures has created rapid growth in employment in producer service activities (Rajan 1985).

Work by Stigler (1951) suggests that the growth of independent producer service firms has come as a result of the need to achieve economies of scale in the main product operations of firms. Different functions require different levels of production to be economic, leading to variations in the externalization of different services (Imrie 1986). Crucial to the decision to externalize is whether or not the service activity in question can be performed outside the firm at lower cost, with no loss in quality, or at higher quality for a similar cost. Typically, subcontracting allows cost savings from greater productivity associated with a more specialized 
Table 1. Geographic Distribution of Service Establishments

\begin{tabular}{|c|c|c|c|}
\hline City & $\begin{array}{c}\text { No. of } \\
\text { Establi stments }\end{array}$ & City & $\begin{array}{c}\text { Ho. of } \\
\text { Establishments }\end{array}$ \\
\hline COLORADO & & UTAH & \\
\hline Denver & 52 & Salt Lake City & 52 \\
\hline Colorado Springs & 20 & Ogden & 6 \\
\hline Englewood & 9 & Park City & 4 \\
\hline Aurora & 9 & Provo & 2 \\
\hline Durango & 8 & Murray & 2 \\
\hline Longmont & 7 & Logan & 1 \\
\hline Greeley & 7 & Sandy & 1 \\
\hline Pueblo & 7 & Midvale & 1 \\
\hline Golden & 4 & West Jordan & 1 \\
\hline Grand Junction & 4 & & \\
\hline Evergreen & 4 & UTAH TOTAL & 70 \\
\hline Littieton & 2 & & \\
\hline Castle Rock & 1 & & \\
\hline Boulder & 1 & & \\
\hline Craig & 1 & & \\
\hline Arvada & 1 & & \\
\hline Woodl and Park & 1 & & \\
\hline Aspen & 1 & & \\
\hline Lakewood & 1 & & \\
\hline Louisville & 1 & & \\
\hline Broomfield & 1 & & \\
\hline Monument & 1 & & \\
\hline COLORADO TOTAL & 144 & & \\
\hline
\end{tabular}


Table 2. Producer Services Provided at Establishments Surveyed

No. of

Activity

Establi shments

ADMINISTRATIVE SERVICES

7

(incl. bookkeeping and accounting.

Payroll, Records, Secretarial

Services and Word Processing)

COMMUNICATION SERVICES

16

(incl. Information Systems and

Television Production)

COMPUTER SERVICES

22

(incl. Systems Development, Data

Processing and Software Development)

CONSULTING

97

(incl. Business Management, Architecture,

Insurance, Surveying. Engineering,

Energy Management, Patent Attorneys,

and Personell Consultants)

EMPLOYMENT SERVICES

24

(incl. Agencies, Human Resources,

Training and Placement)

FINANCIAL SERVICES

11

(incl. Credit Reporting Agencies, Industrial

and Commercial Brokerages, Venture Capital

and Corporate Banking)

MARKETING AND GRAPHICS

33

(incl. Advertising, Telemarketing, Mail

Surveying, Pulbic Relations, Commercial Art and Design)

RESEARCH ANO DEVELOPMENT

(Laboratories)

TOTAL 
Table 3. Establishment Characteristics

\begin{tabular}{|c|c|c|c|}
\hline Establishment type & N & \multicolumn{2}{|c|}{ Employment } \\
\hline Headquarters establishments & 31 & $\begin{array}{l}1-5 \\
6-20 \\
>20\end{array}$ & $\begin{array}{r}3 \\
7 \\
21\end{array}$ \\
\hline Single location establishments & 128 & $\begin{array}{l}1-5 \\
6-20 \\
>20\end{array}$ & $\begin{array}{l}54 \\
55 \\
19\end{array}$ \\
\hline Establishments of multi-site service firms & 48 & $\begin{array}{l}1-5 \\
6-20 \\
>20\end{array}$ & $\begin{array}{l}13 \\
16 \\
19\end{array}$ \\
\hline Establishments of multi-site manufacturing firms & 1 & $\begin{array}{l}1-5 \\
6-20 \\
>20\end{array}$ & $\begin{array}{l}0 \\
0 \\
1\end{array}$ \\
\hline Regional or local sales office & 4 & $\begin{array}{l}1-5 \\
6-20 \\
>20\end{array}$ & $\begin{array}{l}0 \\
0 \\
4\end{array}$ \\
\hline Data entry/data processing & 1 & $\begin{array}{l}1-5 \\
6-20 \\
>20\end{array}$ & $\begin{array}{l}0 \\
0 \\
1\end{array}$ \\
\hline ALL ESTABLISHMENTS & 214 & $\begin{array}{l}1-5 \\
6-20 \\
>20\end{array}$ & $\begin{array}{l}70 \\
78 \\
66\end{array}$ \\
\hline
\end{tabular}


labor force (O'Farrell and Hitchens 1990).

More recent work, however, suggests that the main motivation behind subcontracting is the drive toward increased specialization in service provision, rather than necessarily cost reduction considerations (Stanback et al. 1981; Howells and Green 1988).

A number of additional factors may influence the decision to subcontract. These might be the desire to increase the quality or quantity of service output at a given cost, overcome industrial relations problems, reduce risk and uncertainty associated with certain activities that may be subject to cyclical fluctuations, replace services only used on an irregular basis, provide new services in areas where the firm has no established skills. Some strategic services, such as research and development, may always be provided in-house, while others, such as management consulting and strategic planning may benefit from more objective outside expertise (O'Farrell and Hitchens 1990).

The extent to which service activities are externalized is likely to be closely related to a number of factors, such as industry type, firm size, and type of organization. This raises a number of questions at the regional level. The provision of producer service activities in some regions may be a problem in particular for small firms where there may be limited locally available supply of certain supporting activities. Firms in these areas may use services less intensively than firms in central areas, or may internalize them if there is insufficient local provision, with significant implications for a firm's ability to compete. At other locations, services may be imported without substantially reducing competitiveness.

The extent to which producer service firms maintain internally provided producer service activities, and the type and origin of externalized services is therefore an important planning question. To address this question, establishments in the survey were asked to identify the extent to which producer service activities were provided by local establishments, the rationale for the externalization of service functions, and the geographic sources of producer service imports. These responses are disaggregated into three employment groups, small establishments (1-5 full-time employees), medium-sized establishments (6-20 employees) and large establishments (more than 20 employees).

Table 4 gives shows the extent of externalization of a range of producer service activities by all establishments in the Colorado and Utah sample, and the type of establishment from which these services are typically purchased. The survey also included an additional variable in each table, services purchased from manufacturing firms. These responses were not found to be present in any significant numbers and were excluded from the tables. Activities provided by combinations of establishment types are shown in columns 10 and 11 .

Between $50 \%$ and $70 \%$ of establishments in the sample were found to provide accounting and bookkeeping, payroll and benefits employment services, data processing services and advertising within their establishment, with in most cases roughly an additional $10 \%$ being provided within their firm, at other locations. Service activities more typically subcontracted were consulting services (engineering, architecture and business management), in addition to real estate, banking and legal services. 


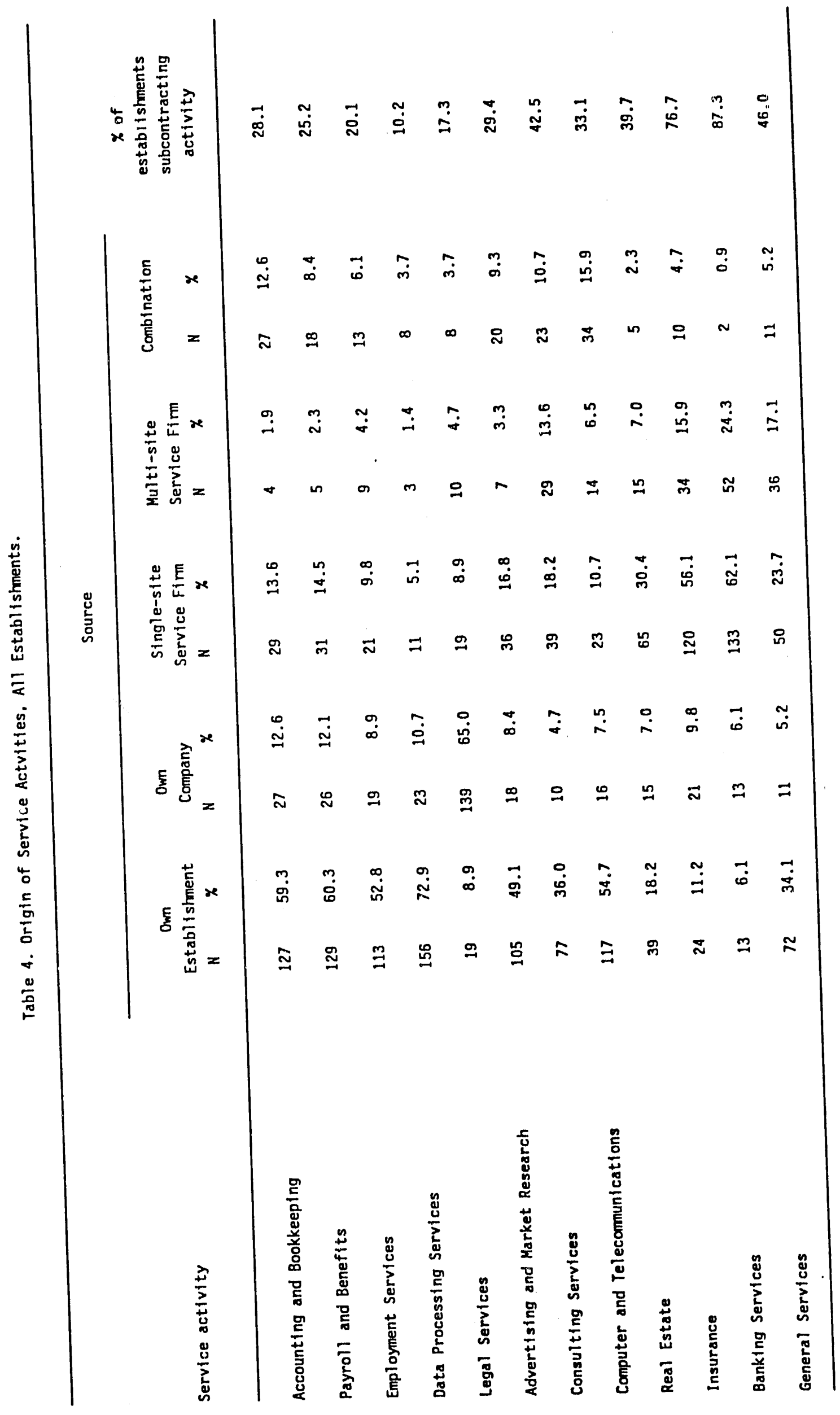


Table 5 shows the sources of services by employment size. The pattern of internalization among producer services provided to small establishments (those between 1 and 5 employees) shows more emphasis placed on the internal provision of services such as accounting etc. payroll, employment services and data processing, than in the sample as a whole. Across establishment sizes, externalization of services seems to be more common among medium sized establishments (those with 6-20 employees) for certain service functions, than for small or large establishments (those with more than 20 employees). The first five service activities seem to be subcontracted by medium sized firms, and maintained internally by small and large establishments. On the other hand, advertising, consulting services and computer and telecommunications services seem to be subcontracted by more medium sized establishments.

These trends seem to reflect the relative levels of specialization demanded by producer service firms as they grow in size, with small firms internalizing basic functions, and subcontracting higher order functions. Medium size firms seem to be externalizing these functions while internalizing more specialist functions. Larger establishments seem to be providing basic service functions internally, and subcontracting certain other functions, such as telecommunications and advertising.

\section{Sources of Business Services for Establishments with Scientific and Technical Occupations}

Although an increasing body of evidence has been collected that relates changes in occupational structure within manufacturing firms to the growth in subcontracting, much less evidence has been collected $f, r$ producer service firms. Just as manufacturing firms require an increase in inputs from independent service activities through the increasing specialization of manufacturing firms, the level of specialization in producer service firms has also increased, requiring an increase in subcontracting of activities to more specialist individual firms.

In order for many producer service activities to compete in regional and national markets, an increasing number of personnel in scientific and technical occupations are needed, and within many firms the proportion of personnel in these occupations has increased markedly in the last twenty years. The need for greater service product quality, design, differentiation and after sales service have generated growth in a range of support activities such as research and development, consulting, market research and advertising. Because many of these activities are being subcontracted to independent producer service firms, the ability of an area to attract producer service activities reliant on highly qualified labor to perform these subcontracted activities is closely linked to the extent to which these firms can locate in smaller metropolitan areas and still succesfully compete in national markets. One solution for firms in this situation might be to import essential inputs from other regions in the U.S.

Producer service establishments with significant scientific and technical occupations were identified indirectly. Establishments were asked to state whether scientific and technical occupations would be important to the choice of a new location, if that location decision were to be made today. Responses were on a scale of 1 to 5 , where 1 was unimportant and 5 was 


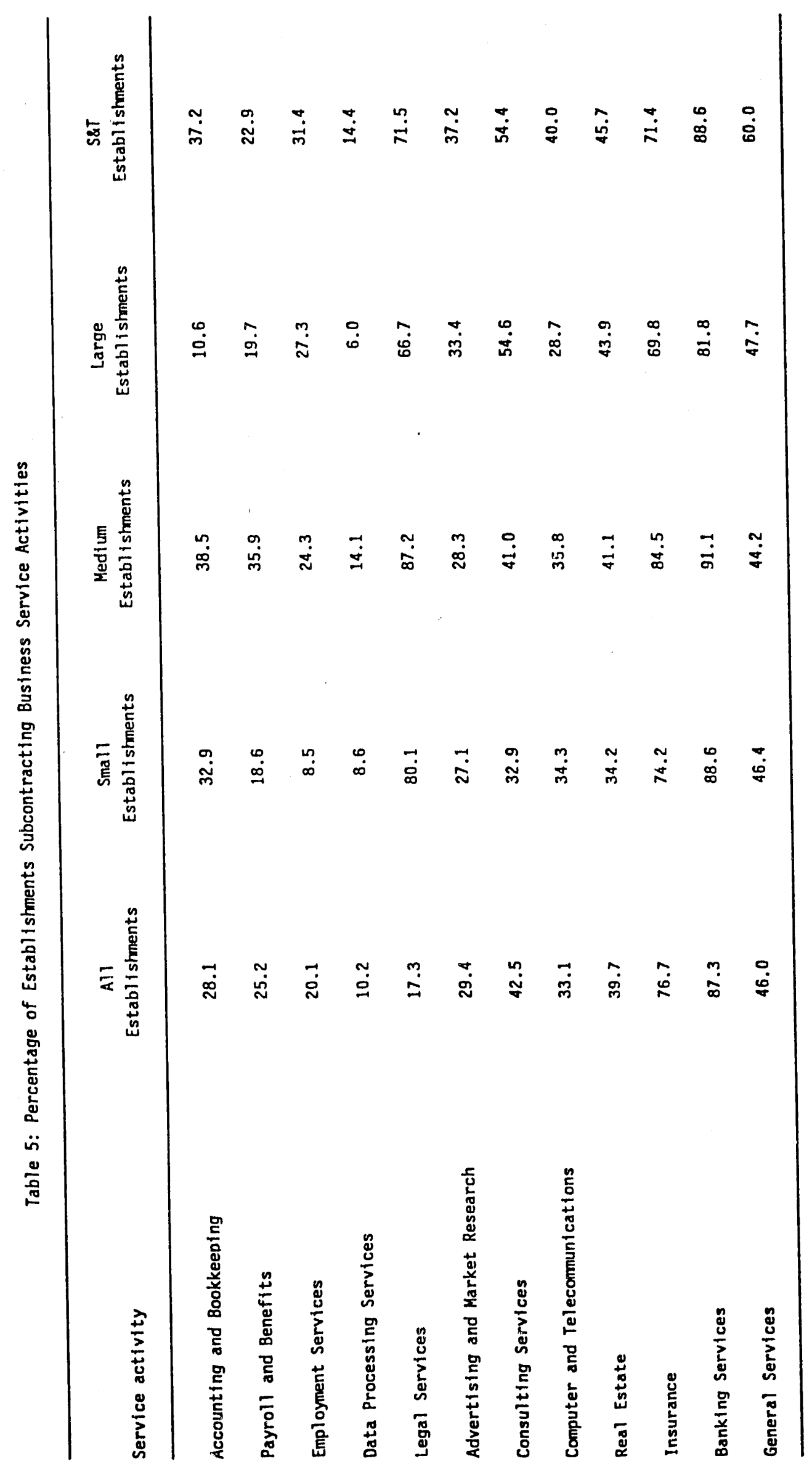


extremely important. Establishments responding 3, 4, or 5 to the question were included in the analysis. 35 firms were identified; 24 were located in Colorado, 11 in Utah. Of these 8 had between 1 and 5 full-time employees, 11 had between 6 and 20 and 15 were larger than 20 .

Table 6 shows the origin of service activities among firms where it could be established that the availability of scientific and technical personnel would be an important factor in the search for a new location. Establishments in this group seemed to rely more heavily on services produced by other branches of the same company than did establishments in the sample as a whole. Some activities in particular were provided less often in the establishments surveyed, than in the sample as a whole. These were accounting and bookkeeping, data processing services, consulting services and general services. These firms externalized significantly more of their legal services to single-site service establishments, and to a lesser extent their accounting bookkeeping activities.

\section{Geographic Sources of Services}

The survey of firms in the two states also identified the geographic sources of subcontracted services. Repondents were asked to provide the names of the cities and state from which they purchased service inputs. Table 7 shows the number of establishments importing subcontracted services, for all establishments, and those reliant on scientific and technical occupations. Sources of services are identified as in-state or out-of-state, with in-state in both Colorado and Utah essentially meaning service provision from within either Denver or Salt Lake City.

Across all firms located in Colorado, only imports of consulting services (14\% of establishments), employment services (12.8\%) and to a lesser extent advertising (13.6\%) from out-of-state locations seem to be important. In Utah service imports seemed to be a more significant phenomenon. Almost $27 \%$ of establishments subcontracting consulting services imported them from other states by firms in Utah, with similar levels of imports of data processing services (25\%) and advertising (22.2\%). Only two service activities were not provided in any significant amount by outside suppliers, legal services $(6 \%)$ and accounting and bookkeeping (0\%).

Imports of service product by producer service firms reliant on scientific and technical uccupations seems to be much more significant than for the figures for all establishments, in both states. $38 \%$ of establishments imported advertising services, $23 \%$ consulting services, $20 \%$ payroll and benefits, and $17 \%$ employment services from out-of-state locations. In Utah these numbers are higher, with $83 \%$ of establishments preferring imports of consulting services, $50 \%$ data processing services, $56 \%$ insurance services and $50 \%$ banking services to services locally produced by other firms. 


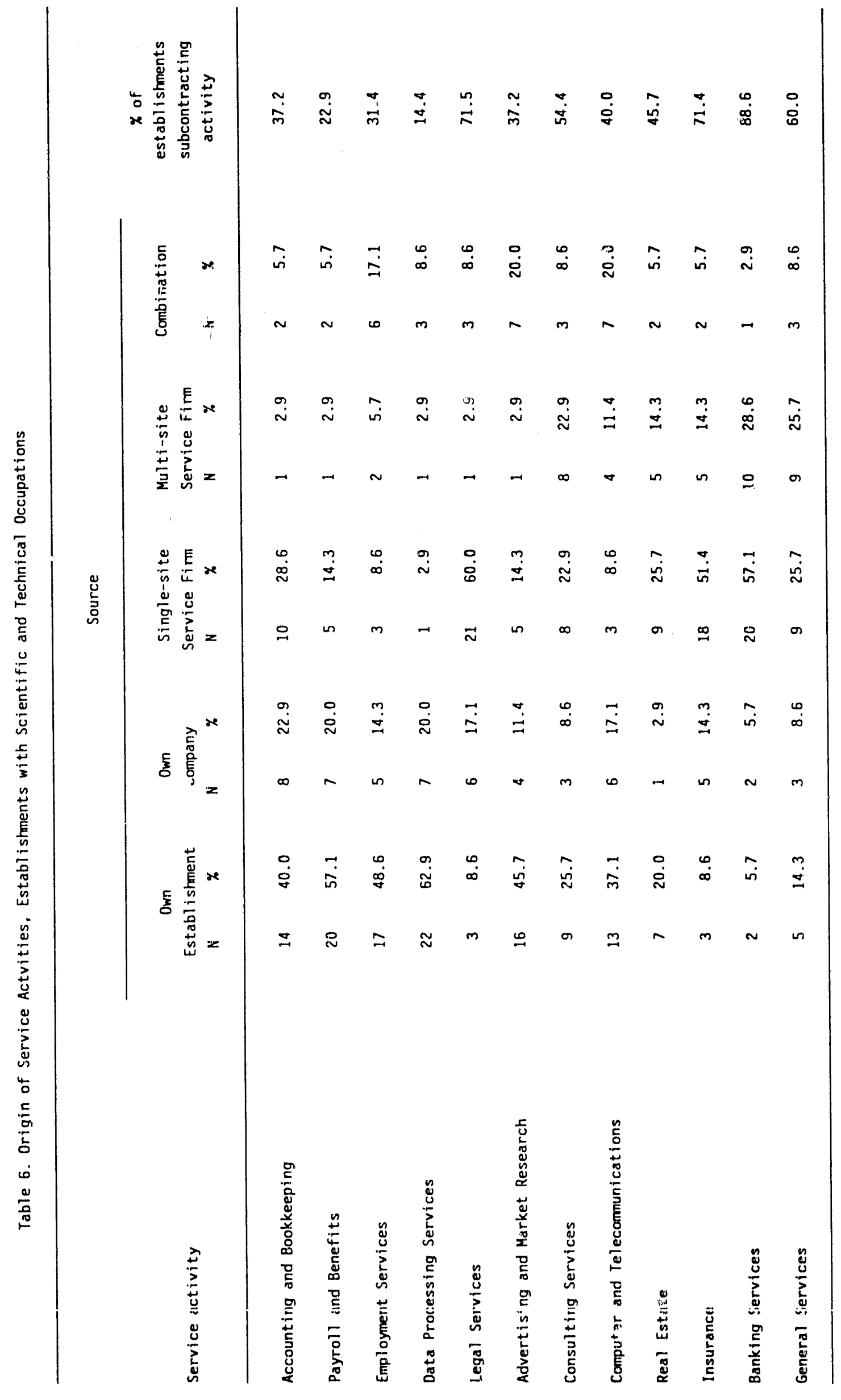




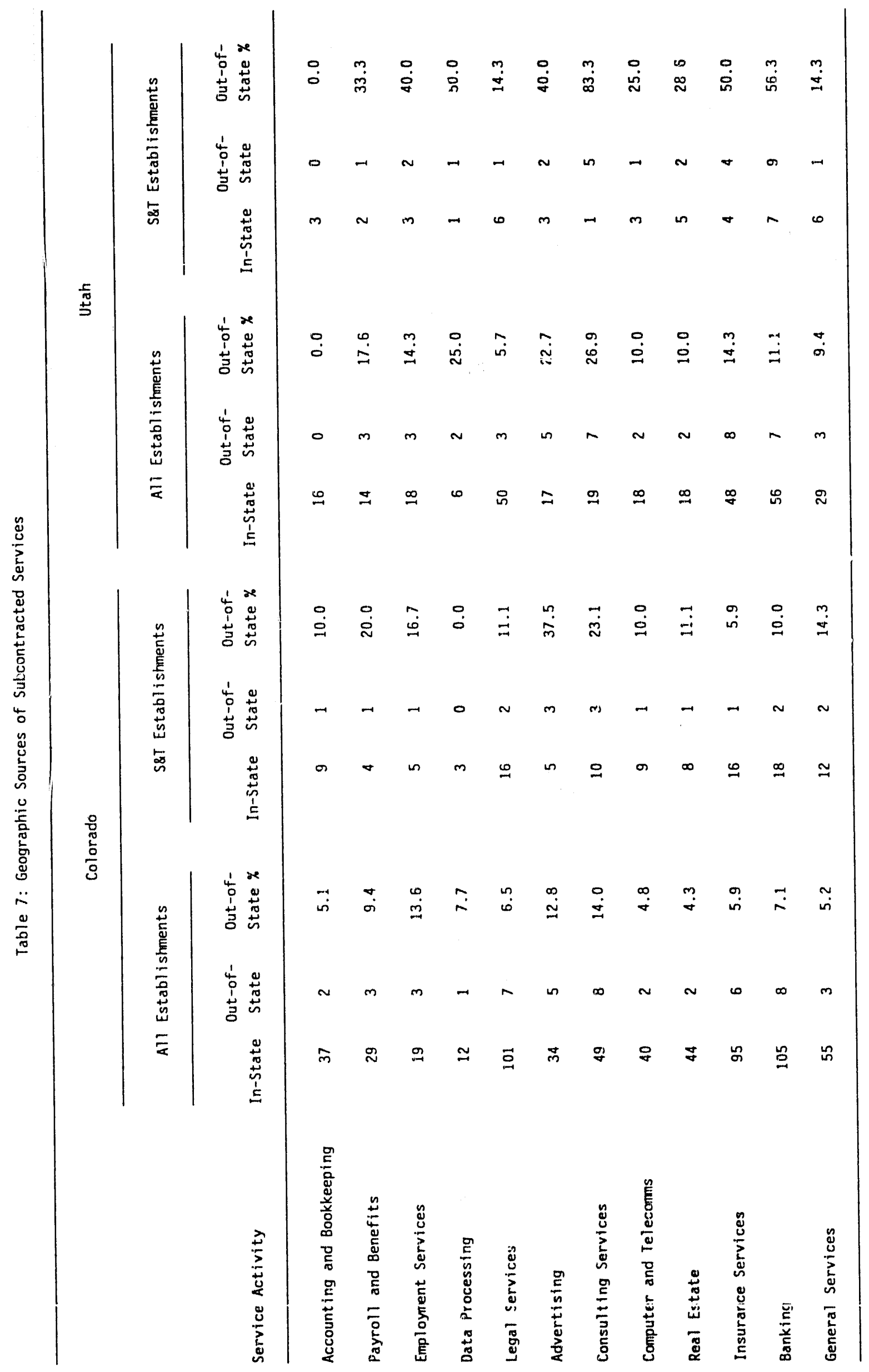




\section{Sectoral and Geographic Distribution of Sales}

Information on the sectoral orientation of priducer service establishmen's in a location provides an indication of the extent to which local producer service firms are independent of other forms of manufacturing and non-manufacturing, activity. It has often been assumed that service activities are dependent on manufacturing as their primary sources of demand, either as activities essentially in support of manufacturing production or that manufacturing provides the most significant market for output of independent producer service firms, meaning that locational patterns of producer service activity reflects that of manufacturing. Independent producer service firms m:y, however constitute a demand source in themselves for the output of business services, in addition to more traditional markets in manufacturing, agriculture, mining and government.

Table 8 outlines the sectoral distribution of sales from the sample of producer service establishments in the sample. Establishments are grouped in the three employment categories, with additional information given on firms reliant on scientific and technical occuaptions. Establishments with less, and more than $50 \%$ of their sales tpo each major sector are shown, with establishments with no sales omitted from the analysis.

For the sample as a whole, establishments with more than $50 \%$ of their total sales seem to be marketing their output primarily to manufacturing (30\%), government $(21 \%)$ and business services $(30 \%)$. Within the sample, however, sales to manufacturing establishments seems to clearly decline with increasing firm size, from $30 \%$ for firms with between 1 and 5 full-time employees, to $7 \%$ for firms with more than 20 full-time employees. Manufacturing sales are replaced by sales to government for medium sized establishments, and to other producer service establishments for the large establishments. Although more precise information could be presented weighting percentage of sales by number of establishments, these data indicate the relative independence of producer servire activities from manufacturing in the Denver and Salt Lake City areas.

In addition to the importance of local agglomeration economies for the provision of input supplies, proximity to markets for producer service firms, increasingly those found in larger regional and national metropolitan areas, are often seen as crucial to the development of a range of successfully competing producer service activities in smaller metropolitan centers and more peripheral regional economies. An increasing body of research has suggested, however, that spatial proximity is not necessarily a crucial issue for certain producer service activities, with the tradability of output from many producer service activities, either through conventional mail services, or via telecommunications linkages that facilitate information transfer, albeit between intermediate and larger urban centers.

Table 9 shows the geographic distribution of sales, with sales by establishments broken down into outside the city/within the state, outside the state/within the U.S., and U.S. exports. Again sales are given for all establishments, the three size groupings and for those establishments reliant on scientific and technical occupations. Figures for all establishments taken together indicate relatively high levels of trading activity outside the home metropolitan area by establishments in the sample. Concentrating at establishments with over $50 \%$ of sales 


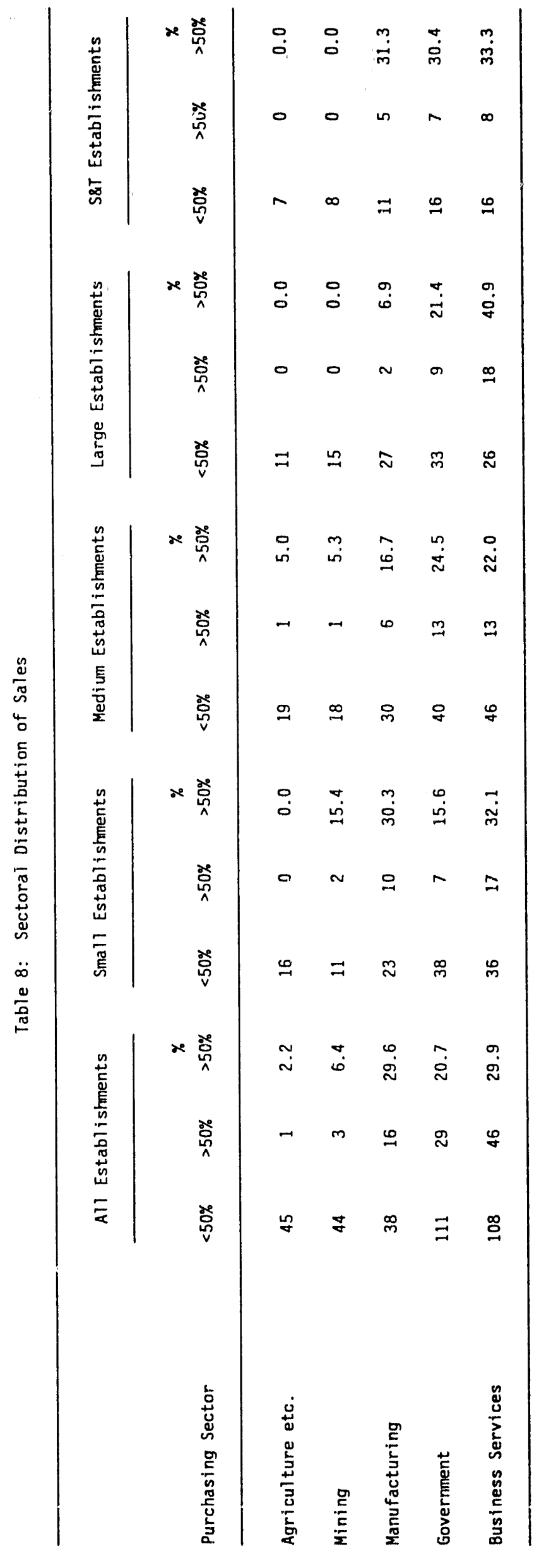







in each geographic category, $16 \%$ of establishments sold services to other parts of the state, almost $18 \%$ exporting from the state to other parts of the U.S., and a little over $5 \%$ exported services from the U.S. Patterns of regional trading by establishments of different employment sizes shows a leaning toward trade in services outside the city for medium sized establishments compared to more activity outside the state for small establishments. Establishments reliant on scientific and technical occupations sold services either to elsewhere within the state, or to overseas customers.

\section{Importance of Environmental Amenities to the Location of Producer Service Establishments.}

The level of environmental amenities, environmental quality and other quality-of-life issues are being cited increasingly as significant factors to the decision to locate a range of producer service activities. Developments in transportation and telecommunications technologies have reduced the costs of marketing products, activities within manufacturing and service firms have become more functionally separated, allowing greater flexibility in choice of location. The growth in subcontracting which in some cases has allowed firms to choose locations based on amenity and quality-of-life considerations.

The importance of amenities to producer service establishments was determined by asking respondents to state whether a various amenity considerations would be important to the choice of a new location, if that location decision were to be made today. Responses were on a scale of 1 to 5 , where 1 was unimportant and 5 was extremely important. Ratings were then calculated by multiplying the number of respondents in each of the categories 2 through 5 by weights, and then dividing by the total number of respondents. The amenities chosen were not necessarily mutually exclusive categories for some respondents. Quality-of-life was used as a catch-all indicator of environmental preferences, for situations where respondents could not state their preferences for specific amenities.

Table 10 shows how important various environmental amenities would be to producer service establishments in their local and regional searches for new locations. A region was defined as a state or multi-state area. Table 10 shows the results for all establishments, for small medium and large establishments, and Table 11 shows the importance of amenities for establishments that rely on scientific and technical occupations.

From Table 10, environmental amenities seemed to be more important to the local than to the regional search for new locations for both small and medium size establishments, possibly reflecting the geographic extent of location searches for establishments of these sizes. Larger establishments rated environmental factors more important to the regional search, reflecting perhaps a wider knowledge base of alternative amenities, greater resources available to search for a new location, or most likely, more flexible criteria for the selection of new sites.

Across amenity categories, the catch-all, quality-of-life seems to be the most important consideration across all establishment sizes, followed by clean air, and lack of congestion and 


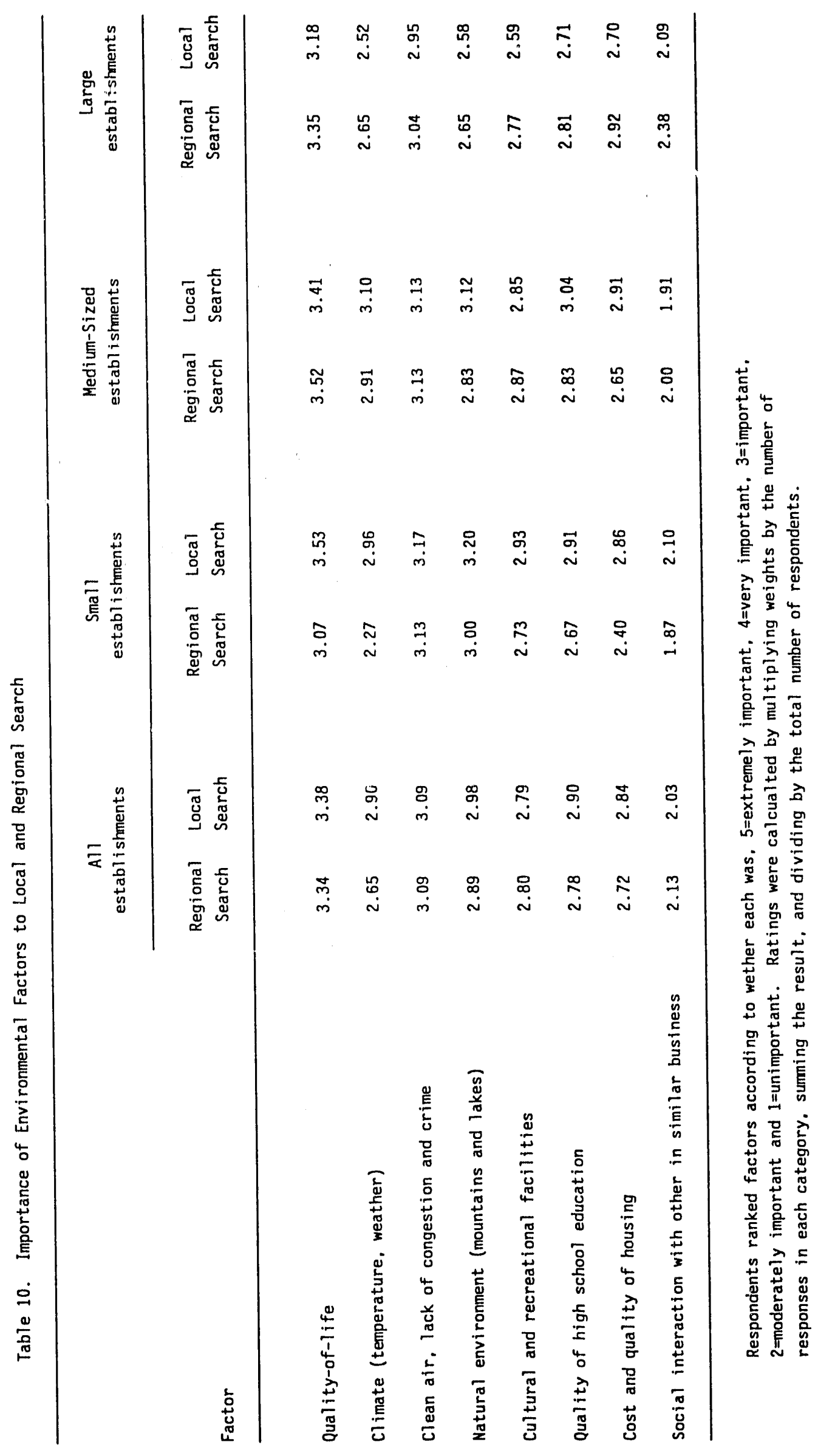




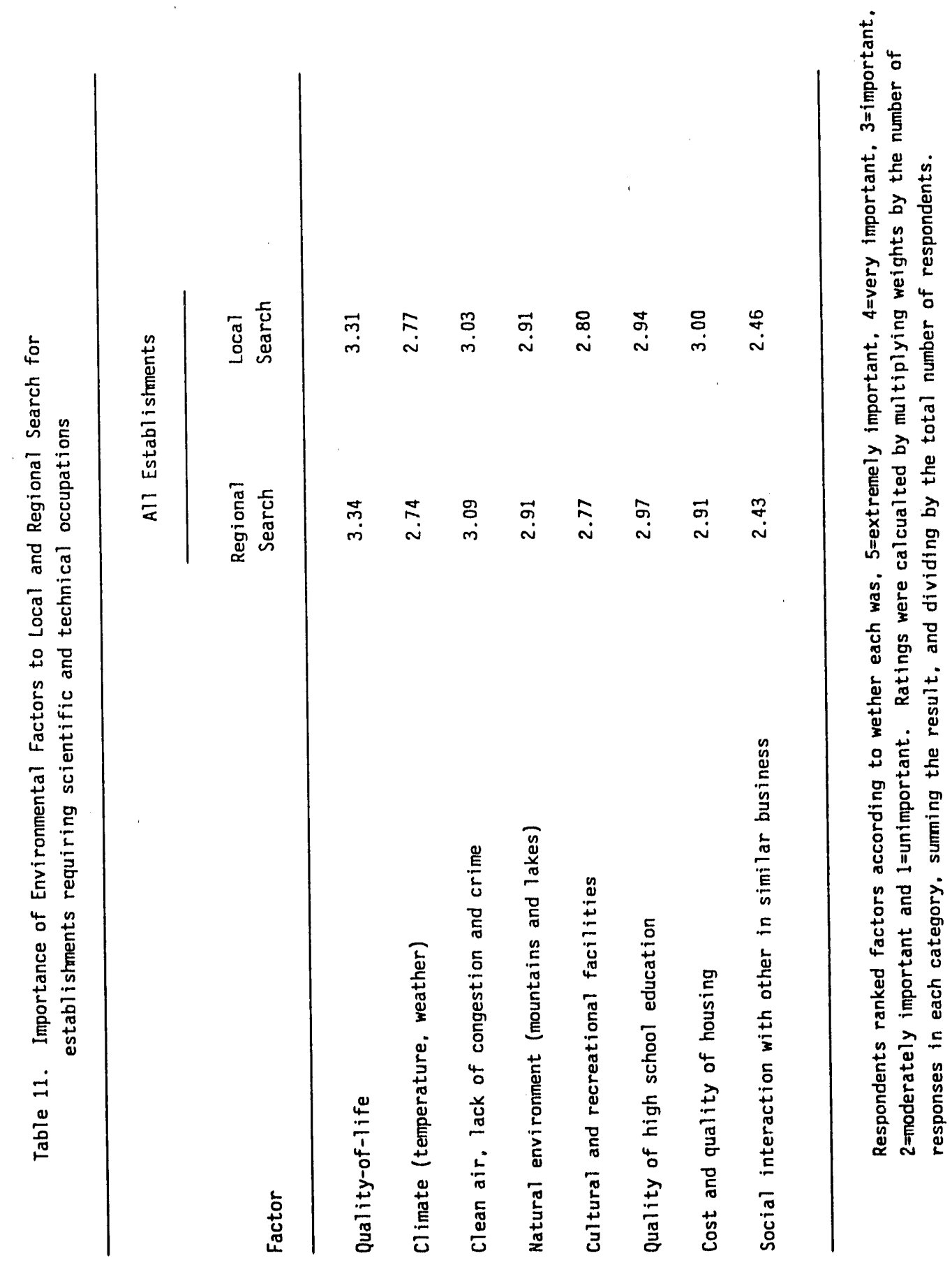


crime. Social interaction with others in the same business, a factor found to be of some importance by Hall et al. (1987), was not rated very highly by respondents.

Establishments with scientific and technical personnel did not rate amenity factors significantly differently from the sample as a whole, although ratings for the regional search were somewhat higher for the majority of the factors than they were in the sample as a whole, and slightly less important for the local search. An important point to note here may be that all establishments in the sample where scientific and technical personnel were staied to important considerations, conducted a regional as well as local search, compared to only $31 \%$ in the sample as a whole.

\section{Conclusions}

From the level of subcontracting of business services by establishments in the sample presented, and the extent of sales by establishments to buyers within and outside the sample region, the producer service establishments seem to show a relatively high level of independence and from the local and regional economy. Many of the necessary supplies of business services to specialized producer service firms are obtained through subcontracts often imported from outside the local economy. Establishments seemed relaitively independent from traditional sources of demand in the manufacturing sector, and sold significant quantities of service product to demand centers located outside the regional economy.

These tendencies seemed more characteristic of producer service establishments reliant on scientific and technical occupations. Establishments exhibiting relatively high degrees of indepedence one might expect to show stronger preferences for environmental considerations, such as the level of natural and cultural amenities. Establishments in the sample seemed to support this hypothesis, gaining support in particular from establishments reliant on scientific and technical occupations.

\section{References}

Beyers, W.B. et al. 1985. "The Service Economy: Export of Services in the Central Puget Sound Region" Seattle, Central Puget Sound Development District.

Coffey, W.J. and Polese, M. 1989. "Producer Services and Regional Development: A PolicyOriented Perspective". Papers of the Regional Science Association 67: 13-27.

Coffey, W.J. 1987. "Trade and Location of Producer Services: A Canadian Perspective". Environment and Planning: A, 19: 597-611.

Daniels, P.W. (ed.) 1985. Service Industries. Matheun, New York. 
Drennan, M.P. 1989. "Information Intensive Industries in Metropolitan Areas of the United States of America". Environment and Planning: A 21: 1603-1618.

Hall, P., et al., 1987, Western Sunrise: The Genesis and Growth of Britain's Major HighTech Corridor, Allen Unwin, Boston MA.

Howells, J. and Green, A. 1988. Technological Innovation, Structural Change and Location in UK Services Brookfield. Gower.

Imrie, R.F. 1986. "Work Decentralization from Large to Small Firms: A Preliminary Analysis of Subcontracting". Environment and Planning: A 18: 949-965.

Marshall, J.N. 1985. "Business Services, the Regions and Regional Policy". Regional Studies 19: 353-363.

Marshall, J.N. 1983. "Business-Service Activities in British Provincial Conurbations". Environment and Planning: A 15: 1343-1359.

Noyelle, T.J. and Stanback, T.M. 1984. The Economic Transformation of American Cities Totowa, NJ. Rowman \& Allanheld.

O'Farrel, P.N. and Hitchens, D.M.W.N. 1990. "Research Policy and Review 32. Producer Services and Regional Development: A Review of Some Major Conceptual Policy and Research Issues". Environment and Planning: A 22: 1141-1154.

Rajan, A. 1985. "Service Industry: Consumer or Creator of National Wealth?". Futures 17: $52-56$.

Stanback, T.M., et al. 1981. Services: The New Economy. Totowa NJ. Allanheld, Osman.

Stigler, G.J. 1951. "The Division of Labour is Limited by the Extent of the Market". Journal of Political Economy 59: 185-193. 
a.

.

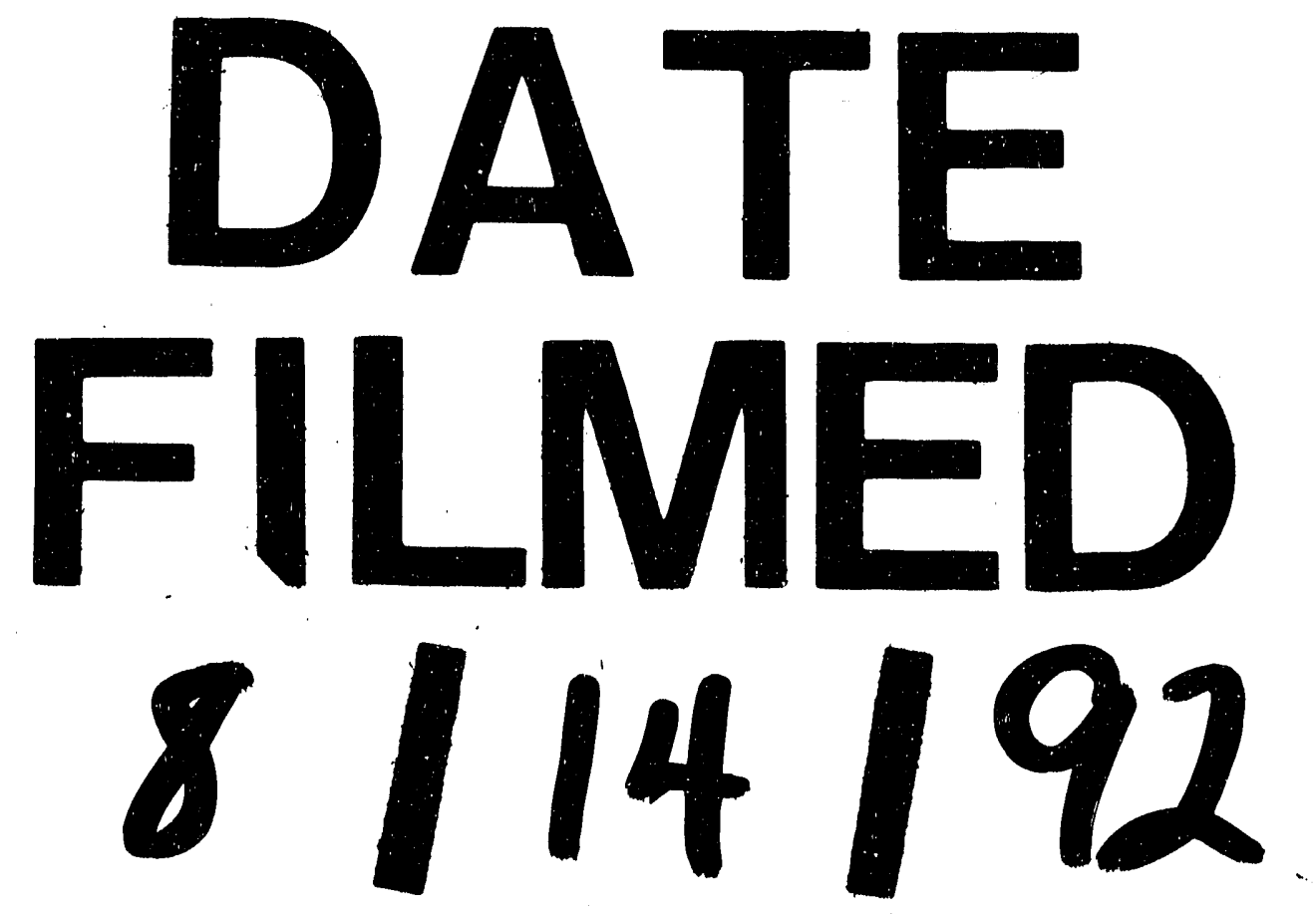

高 
